\title{
Genetics of Isolated Growth Hormone Deficiency
}

\author{
Primus E. Mullis ${ }^{1}$ \\ ${ }^{1}$ Inselspital, Division of Paediatric Endocrinology, Diabetology\&Metabolism, University Children's Hospital, Bern, Switzerland
}

\begin{abstract}
When a child is not following the normal, predicted growth curve, an evaluation for underlying illnesses and central nervous system abnormalities is required, and appropriate consideration should be given to genetic defects causing growth hormone (GH) deficiency (GHD). Because Insulin-like Growth Factor-I (IGF-I) plays a pivotal role, GHD could also be considered as a form of IGF-I deficiency (IGFD). Although IGFD can develop at any level of the GH-releasing hormone (GHRH)-GH-IGF axis, a differentiation should be made between GHD (absent to low GH in circulation) and IGFD (normal to high GH in circulation). The main focus of this review is on the GH gene, the various gene alterations and their possible impact on the pituitary gland. However, although transcription factors regulating the pituitary gland development may cause multiple pituitary hormone deficiency, they may present initially as GHD.

Key words: Growth, human $\mathrm{GH}$-gene cluster, isolated growth hormone deficiency, children
\end{abstract}

Received: 22.04 .2010

Accepted: 04.05.2010

\section{Introduction}

Historically, over the last decades, growth disorders were managed on the basis of a growth hormone $(\mathrm{GH})$-oriented classification system. However, nowadays we are well aware that: a) $\mathrm{GH}$ is not the major mediator of skeletal growth; b) scepticism as well as criticisms are adequate and accepted while analyzing the variable results of the various $\mathrm{GH}$ stimulation tests; c) many genetic defects have been described and, therefore, have presented important insights into the molecular basis of also non-GH deficient growth failure.

Therefore, when a child is not following the normal, predicted growth curve, an evaluation for underlying illness and central nervous system abnormalities is required. Where appropriate, genetic defects causing $\mathrm{GH}$ deficiency (GHD) should be considered. Because Insulin-like Growth Factor-I (IGF-I) plays a pivotal role in growth, where it mediates most, if not all, of the effects of $\mathrm{GH}$, in fact GHD could also be considered somehow as secondary IGF-I deficiency (IGFD). Although IGFD can develop at any level of the GH-releasing hormone (GHRH)-GH-IGF axis, we would like to differentiate, however, between GHD (absent to low $\mathrm{GH}$ in circulation) and IGFD (normal to high $\mathrm{GH}$ in circulation). The main focus of this review is on the $\mathrm{GH}$ gene cluster, the $\mathrm{GHRH}$ - as well as the GHRH-receptor-gene.

\section{Classification of Isolated Growth Hormone Deficiency}

\section{Structure and Function of GH and CS Genes}

The $\mathrm{GH}$ gene cluster consists of five structurally similar genes in the order 5' [GH-1, CSHP (chorionic somatomammotropin pseudogene), $\mathrm{CSH}-1$ (chorionic

\section{Address for Correspondence}

Primus E. Mullis, Division of Paediatric Endocrinology, Diabetology\&Metabolism, University Children's Hospital, Inselspital, CH-3010 Bern, Switzerland Phone: +41316329552 Fax: +41316329550 E-mail: primus.mullis@insel.ch 
somatomammotropin gene), GH-2, CSH-2] 3' encompassing a distance of about $65,000 \mathrm{bp}(65 \mathrm{~kb})$ on the long arm of chromosome 17 at bands q22-24(1). The GH-1 gene encodes the mature human $\mathrm{GH}$, a 191-amino acid (aa) peptide, and consists of five exons and four introns (1-3). Approximately $75 \%$ of circulating $\mathrm{GH}$ is expressed in the anterior pituitary gland as a major 22-kDa product, whereas alternative splicing can give rise to minor forms (2-4). The most prominent minor form $(5-10 \%)$ is a bioactive $20-k D a$ GH peptide isoform that results from the use of a cryptic 3' splice site in E3, deleting aa 32-46 (4-7). The GH-2 gene encodes a protein $(\mathrm{GH}-\mathrm{V})$ that is expressed in the placenta rather than in the pituitary gland and differs from the primary sequence of $\mathrm{GH}-\mathrm{N}$ (product of $\mathrm{GH}-1$ gene) by 13 aa. This hormone replaces pituitary $\mathrm{GH}$ in the maternal circulation during the second half of pregnancy. The CSH-1, $\mathrm{CSH}-2$ genes encode proteins of identical sequences, whereas the CSHP encodes a protein that differs by 13 aa and contains a mutation (donor splice site of its second intron) that should alter its pattern of mRNA splicing and, therefore, the primary sequence of the resulting protein. The extensive homology (92-98\%) between the immediate flanking, intervening, and coding sequences of these 5 genes suggests that this multigene family arose through a series of duplicational events. With the exception of CSHP, each gene encodes a 217 aa pre-hormone that is cleaved to yield a mature hormone with 191-aa and a molecular weight of $22 \mathrm{kDa}$. The expression of $\mathrm{GH}-1$ gene is further controlled by cis- and trans-acting elements and -factors, respectively (2-8).

\section{Familial Isolated GHD}

Short stature associated with GHD has been estimated to occur in about 1/4,000 -1/10,000 in various studies (9-11). While most cases are sporadic and are believed to result from environmental cerebral insults or developmental anomalies, $3-30 \%$ of cases have an affected first-degree relative suggesting a genetic aetiology. Since magnetic resonance examinations detect only about 12-20\% anomalies of either hypothalamus or pituitary gland in isolated GHD (IGHD), it can be assumed that many genetic defects may not be diagnosed and a significantly higher proportion of sporadic cases may have indeed a genetic cause (12). Familial IGHD, however, is associated with at least four Mendelian disorders (2-8), including two forms that have autosomal recessive inheritance (IGHD type IA, IB) as well as autosomal dominant (IGHD type II) and X-linked (IGHD III) forms. Table 1 depicts the mutational spectrum of GHD, which is discussed in greater detail later in the review.

\section{IGHD Type IA}

In 1970, IGHD type IA was first described by Ruth IIlig in three Swiss children with unusually severe growth impairment and apparent deficiency of GH (13). Affected individuals occasionally have short length at birth and hypoglycaemia in infancy, but uniformly develop severe growth retardation by the age of six months. Their initial good response to exogenous $\mathrm{GH}$ is hampered by the development of anti-GH-antibodies leading to dramatic slowing of growth $(2,14)$.

\section{GH-1 Gene Deletions}

In 1981, Phillips et al (14) examined the genomic DNA from these Swiss children and discovered, using Southern blotting technique that the $\mathrm{GH}-1$ gene was missing. Subsequently, additional cases of $\mathrm{GH}-1$ gene deletions have been described responding well to the $\mathrm{GH}$ treatment. The development of anti-GH antibodies is an inconsistent finding in IGHD IA patients despite the presence of identical molecular defects (homozygosity for $\mathrm{GH}-1$ gene deletions) (15). The frequency of $\mathrm{GH}-1$ gene deletions as a cause of GHD varies among different populations and according to the chosen criteria and definition of short stature (1). The sizes of the deletions are heterogeneous with the most frequent $(70-80 \%)$ being $6.7 \mathrm{~kb}(2,8)$. The remaining deletions described include $7.6,7.0,45 \mathrm{~kb}$, as well as double deletions within the $\mathrm{GH}$ gene cluster $(2,8)$. At the molecular level, these deletions involve unequal recombination and crossing over within the $\mathrm{GH}$-gene cluster at meiosis (2).

\section{GH-1 Gene Frameshift- and Nonsense Mutations}

Single-base pair deletions and nonsense mutations of the signal peptide may result in an absent production of mature $\mathrm{GH}$ and in the production of anti-GH-antibodies on exogenous replacement therapy (8,16-19).

\section{IGHD Type IB}

Patients with IGHD type IB are characterized by low but detectable levels of $\mathrm{GH} \quad(<7 \mathrm{mU} / \mathrm{l} ;<2.5 \mathrm{ng} / \mathrm{ml})$, short stature ( $<-2$ SDS for age and sex), growth deceleration and height velocity less than $25^{\text {th }}$ percentile for age and sex, significantly delayed bone age, an autosomal recessive inheritance (two parents of normal height; two sibs affected), no demonstrable direct and/or endocrine cause for IGHD, and a positive response and immunological tolerance to treatment with exogenous $\mathrm{GH}$. This subgroup of IGHD has been broadened and reclassified on the basis of the nature of their $\mathrm{GH}$ gene defects and includes splice site mutations of the $\mathrm{GH}$ gene, even an apparent lack of $\mathrm{GH}$ has been found by RIA. The phenotype of IGHD type IB, therefore, is more variable than IA. In one family, the children may resemble IGHD type IA, whereas in other families, growth during infancy is relatively normal and growth failure is not noted until mid-childhood. Similarly, $\mathrm{GH}$ may be nearly lacking or simply low following stimulation test. This heterogeneous phenotype suggests that there is more than one candidate gene causing the disorder, as summarized recently. 
Candidate Genes in IGHD Type IB

Some of the components of the $\mathrm{GH}$ pathway are unique to $\mathrm{GH}(18,20)$, whereas many others are shared. In patients with IGHD, mutational changes in genes specific to the $\mathrm{GHRH}-\mathrm{GH}$ axis are of importance and there is a need to focus on them.

\section{GHRH-Gene}

Many laboratories put a lot of energy to define any GHRH gene alterations. To date, no GHRH gene mutations or deletions causing IGHD have been reported $(8,21,22)$.
This is, however, somewhat a surprising observation, and the GHRH gene must still be considered a candidate gene for familial forms of IGHD.

\section{GHRH-Receptor (GHRHR) Gene}

In 1992, Kelly Mayo cloned and sequenced the rat and human GHRH-receptor (GHRHR) gene that provided the opportunity to examine the role of GHRHR in growth abnormalities that involve the $\mathrm{GH}$-axis (23). Sequencing of the GHRHR gene in the little-mouse (lit/lit) showed a single nucleotide substitution in codon 60 that changed aspartic

Table 1. Mutational spectrum of GH-deficiency

\begin{tabular}{|c|c|c|c|c|}
\hline \multicolumn{5}{|c|}{ Microdeletions } \\
\hline Deficiency type & Deletion & Codon & GH-antibodies on treatment & References \\
\hline IA & TGcCTG & -10 & yes & 16 \\
\hline IA & GGCcTGC & -12 & yes & Mullis unpublished \\
\hline II & CGGggatggggagacctgtaGT & $5^{\prime}$ IVS-3 del+28 to +45 & no & 68 \\
\hline IA & GagTCTAT & 55 & no & 17 \\
\hline \multicolumn{5}{|c|}{ Single base-pair substitutions in the $\mathrm{GH}-1$ gene coding region } \\
\hline Deficiency type & Mutation & Codon nucleotide & $A B$ on treatment & References \\
\hline IA & $\begin{array}{l}\text { TGG }>>\text { TAG } \\
\text { Trp }>>\text { stop }\end{array}$ & -7 & yes & 18 \\
\hline IA & $\begin{array}{l}\text { GAG }>\text { TAG } \\
\text { Glu }>>\text { stop }\end{array}$ & -4 & no & 19 \\
\hline II & $\mathrm{R} 183 \mathrm{H}$ & G6664A & no & 77 \\
\hline II & V110F & G6191T & no & 65 \\
\hline II & P89L & С6129T & no & 78 \\
\hline II / bio-inactivity & $\begin{array}{l}\text { CGC -TGC } \\
\text { Arg }->\text { Cys }\end{array}$ & 77 & no & $101-105$ \\
\hline \multicolumn{5}{|c|}{ Single base-pair substitutions affecting mRNA splicing } \\
\hline Deficiency type & 5'IVS-3 & $\Delta$ exon 3 & Origin & References \\
\hline II & GTGAGT -> GTGAAT & yes & Chile & 51 \\
\hline II & GTGAGT -> GTGACT & yes & Turkey & Mullis unpublished \\
\hline II & GTGAGT $->$ GTGAGC & yes & Turkey, Asia & 62 \\
\hline II & $\mathrm{GT} \rightarrow \mathrm{AT}$ & yes & Europe, America, Africa & 63 \\
\hline II & $\mathrm{GT} \rightarrow \mathrm{CT}$ & yes & Turkey & 64 \\
\hline II & $\mathrm{GT}->\pi$ & yes & India & Mullis unpublished \\
\hline \multirow[t]{2}{*}{$\underline{\text { II }}$} & $\mathrm{GT} \rightarrow \mathrm{GC}$ & yes & Germany, Holland & 65 \\
\hline & Exon splice enhancer & yes & & \\
\hline II & ESE1m1:+1G-> T & yes & Japan & 69 \\
\hline II & ESE1m2:+2A->C & yes & Switzerland & Mullis unpublished \\
\hline \multirow[t]{2}{*}{ II } & ESE1m3:+5A-> G & yes & & 70 \\
\hline & Intron splice enhancer & yes & & \\
\hline II & ISEm1:IVS-3 +28 G -> A & yes & & 68 \\
\hline \multirow[t]{2}{*}{ II } & ISEm3:IVS-3 del28-45 & yes & & 68 \\
\hline & Length of the intron & yes & & \\
\hline \multirow[t]{2}{*}{ II } & IVS3 del56-77 & yes & Italy & 76 \\
\hline & 5'IVS-4 & & & \\
\hline IB & $\mathrm{GT}->\mathrm{CT}$ & no & Saudi Arabia & 18 \\
\hline IB & $\mathrm{GT}->\mathrm{TT}$ & no & Saudi Arabia & 20 \\
\hline
\end{tabular}


acid to glycine (D60G) eliminating the binding of GHRH to its own receptor (24). As the phenotype of IGHD type IB in humans has much in common with the phenotype of homozygous lit/lit mice including autosomal recessive inheritance, time of onset of growth retardation, diminished secretion of GH and IGF-I, proportional reduction in weight and skeletal size, and delay in sexual maturation, the GHRHR gene was searched for alteration in these patients suffering from IGHD type IB $(25,26)$. Wajnrajch et al (26) reported a nonsense mutation similar to the little mouse in an Indian Muslim kindred. Furthermore, in two villages in the Sindh area of Pakistan, Baumann (27) reported another form of severe short stature caused by a point mutation in the GHRHR gene resulting in a truncation of the extracellular domain of this receptor. Individuals who are homozygous for this mutation are very short (-7.4 SDS) but normally proportioned. They appear to be of normal intelligence, and at least some are fertile. Biochemical testing revealed that they have normal levels of GHRH and GH binding protein (GHBP), but undetectable levels of $\mathrm{GH}$ and extremely low levels of IGF-I. Later, families from Sri Lanka, Brazil, United States, Spain as well as Pakistan were reported (28-31). Mutations in the GHRHR gene have been described as the basis for a syndrome characterized by autosomal recessive IGHD and anterior pituitary hypoplasia, defined as pituitary height more than 2 SD below age-adjusted normal, which is likely due to depletion of the somatotrop cells (OMIM: 139190). In a most recent report, however, certain variability in anterior pituitary size even in siblings with the same mutation was described (32). This finding is of importance, as it was thought that patients with a GHRHR gene defect invariably have an anterior pituitary gland hypoplasia and that GHRHR gene mutations can be excluded in the absence of this pathological feature, because GHRHR may be critical for pituitary gland development and function of the somatotropes $(33,34)$. Further, Hilal et al (35) discussed most interestingly the possible role of GHRHR in the proper development of extrapituitary structures, through a mechanism that could be direct or secondary to severe GHD.

Overall, mutations in the human GHRHR gene can impair ligand binding and signal transduction, and have been estimated to cause about $10 \%$ of autosomal recessive familial IGHD (36). Mutations reported to date include six splice donor site mutations, two microdeletions, two nonsense mutations, seven missense mutations, and one mutation in the promoter $(35,36)$. These mutations have an autosomal recessive mode of inheritance, and heterozygous individuals do not show signs of IGHD, although the presence of an intermediate phenotype has been hypothesized. Conversely, patients with biallelic mutations have low serum IGF-1 and GH levels (with absent or reduced $\mathrm{GH}$ response to exogenous stimuli), resulting - if not treated- in proportionate dwarfism $(36,37)$.

\section{Muscarinic Acetylcholine Receptor ( $m A c h R$ )}

Acetylcholine, as a neurotransmitter, exerts many of its actions via interaction with one or more of the five mammalian muscarinic acetylcholine receptor (mAchR) subtypes, M1-M5. The importance of cholinergic pathways in the regulation of $\mathrm{GH}$ secretion in humans is well established. Central cholinergic stimulation gives rise to an increase in $\mathrm{GH}$ release, whereas cholinergic blockade is followed by a blunting in GH secretion (38). Acetylcholinesterase inhibitors, which indirectly activate cholinergic neurotransmission, are believed to act by reducing the release of somatostatin (SRIF), thus increasing spontaneous $\mathrm{GH}$ secretion, and potentiating $\mathrm{GH}$ responses to $\mathrm{GHRH}$ or to other stimuli. Conversely, muscarinic cholinergic receptor antagonist drugs reduce spontaneous $\mathrm{GH}$ release as well as $\mathrm{GH}$ responses to GHRH, sleep, exercise, L-dopa, glucagon, arginine, and clonidine. Mouse models have been generated, in which a specific subtype of mAchR has been ablated by genetic engineering (39). These animals have a wide variety of phenotypic abnormalities but not growth failure, seemingly showing, that at least in rodents, the lack of muscarinic receptor function would not cause a significant reduction in $\mathrm{GH}$ secretion. However, very recently a murine model was created, in which the function of the M3 receptor was ablated in both alleles exclusively in the central nervous system (40). In this model, body length is reduced, and this is associated with significantly reduced $\mathrm{GH}$ and IGF-I serum levels and a reduction in pituitary somatotroph cell mass. Although the degree of growth retardation and pituitary hypoplasia is not as marked, the phenotype of this animal has a striking similarity with the murine model of ablation of the GHRH gene (41), and with the naturally occurring mutation in the GHRHR gene that occurs in the little mouse (24). These observations are consistent with the hypothesis that the neuronal muscarinic receptors play an important role in controlling $\mathrm{GH}$ secretion. Based on all the above observations, we hypothesized that a subgroup of IGHD type IB families may have inactivating mutations in these receptors. To test this hypothesis, we analyzed the M1-M5 receptor genes in 39 of these families.

However, we concluded from this study that mAchR mutations are absent or rare (less than 2.6\%) in familial IGHD type IB (42).

Ghrelin Receptor, GH Secretagogue Receptor (GHSR)

To date, there is one recent report describing a loss of function of the constitutive activity of the GH secretagogue receptor (GHSR) in familial short stature $(43,44)$. GHSR is highly expressed in the brain and in the pituitary gland. The first endogenous ligand of this receptor was discovered back in 1999 and was named ghrelin (45). Although pharmacological studies have demonstrated that this 
endogenous ligand stimulates, through the GHSR, GH secretion and appetite, the physiological importance of the GHSR-dependent pathways remains an open question that gives rise to much controversy (43).

\section{Homeobox Gene Expressed in ES Cells; HESX1}

It has been shown that familial septo-optic dysplasia (SOD), a syndromic form of congenital hypopituitarism involving optic nerve hypoplasia and agenesis of midline brain structures, may be associated with homozygosity for an inactivating mutation in the homeobox gene hesx $1 / \mathrm{HESX} 1$. Importantly, a small proportion of mice heterozygous for the hesx 1 null allele show a milder form of SOD, implying that heterozygosity in human HESX1 gene alteration may lead to a mild phenotype of IGHD only (46). Therefore, actually the HESX1 gene has to be studied whenever looking for any molecular reason causing IGHD type IB (47).

\section{SOX3 SRY (Sex Determining Region Y)-Box 3}

SOX3 is located on the $\mathrm{X}$-chromosome and both under- and overdosages of the gene lead to hypopituitarism $(48,49)$. Male patients present with variable hypopituitarism (combined pituitary hormone deficiency (CPHD) or IGHD) and infundibular hypoplasia, an ectopic/undescended posterior pituitary and abnormalities of the corpus callosum with or without mental retardation, in other words, this gene needs a closer look as well while studying IGHD $(47,50)$.

\section{Specific Trans-Acting Factor to GH-Gene}

Any alteration to the specific transcriptional regulation of the GH-1 gene may produce IGHD type IB. Mullis et al (51) have reported a heterozygous 211 base pairs (bp) deletion within the retinoic acid receptor a gene causing the phenotype of IGHD type IB.

\section{Transcription Factors, Important for}

\section{Pituitary Gland Development}

In addition, as the occurrence of the various hormonal deficiencies caused by transcription factors important for the pituitary gland development may vary quite drastically also with a family presenting with an identical gene defect, GHD can be the only defect at the beginning. Therefore, the two most important transcription factors, namely POU1F1 (Pit-1) and PROP 1, are shortly discussed (Table 2).

\section{POU1F1 (PIT1)}

The pituitary transcription factor PIT-1 is a member of the POU-family of homeoproteins, which regulates important differentiating steps during embryological development of the pituitary gland as well as target gene function within the postnatal life (8). Further, it is 291 aa in length, contains a transactivation domain and two conserved DNA-binding domains: the POU-homeodomain and the POU-specific domain. As PIT1 is confined to the nuclei of somatotropes, lactotrops and thyrotropes in the anterior pituitary gland, the target genes of PIT1 include the $\mathrm{GH}-$, prolactin- (PRL) and the thyrotropin (TSH)-subunit-, and the POU1F1 gene itself. Therefore, the defects in the human POU1F1 gene known so far have all resulted in a total deficiency of $\mathrm{GH}$ and $\mathrm{PRL}$, whereas a variable hypothyroidism due to an insufficient TSH secretion, at least during childhood, has been described (Table 2). Although it is important to stress that the clinical variability is due to other factors than the exact location of the mutation reported, the type of inheritance, however, seems to correlate well with the genotype. The first mutation within the POU1F1 gene was identified by Tatsumi (52). The majority of the mutations reported so far are recessive, however, a number of heterozygous point mutations have been reported (53). Of those, the aa substitution R271W (Arg271Trp) seems to be a "hotspot". Further, the dominant negative effect of the R271W POU1F1 form has been recently challenged by Kishimoto et al (54). Although most cases with R271W were sporadic and presenting with an autosomal dominant mode of inheritance, Okamoto et al (55) reported a family with normal family members, who were clearly heterozygous for that mutation. Therefore, further in vitro expression studies were performed that could not confirm its dominant negative effect, which is well in contrast with the original report using identical experimental conditions $(8,54)$.

\section{PROP1}

Wu et al (56) described four families, in which CPHD was associated with homozygosity or compound heterozygosity for inactivating mutations of the PROP1 gene. PROP1 (prophet of Pit1) is a paired-like homeodomain transcription factor and, originally, a mutation in this gene (Ser83Pro) was found causing the Ames dwarf (df) mouse phenotype (57). In mice, Prop1 gene mutation primarily causes GH, PRL and TSH deficiency, and in humans, PROP1 gene defects also appear to be a major cause of CPHD. In agreement with the model of Prop1 playing a role in commitment of dorsal lineages (GH, PRL and TSH), Prop1 mutant mice exhibit a dorsal expansion of gonadotrophs that normally arise on the ventral side.

To date, many different missense, frameshift and splice site mutations, deletions, insertion have been reported and it has been realized that the clinical phenotype varied not only among the different gene mutations, but also among the affected siblings with the same mutation $(58,59)$. In addition, although the occurrence of the hormonal deficiency varies from patient to patient (8), the affected patients as adults were not only GH, PRL and TSH deficient, but also gonadotropin deficient (Table 2). The three tandem repeats of the dinucleotides GA at location 296-302 in the PROP1 gene represent a "hot-spot" for CPHD (58-60). Low levels of cortisol have also been described in some patients with PROP1 gene mutations (61). In addition, pituitary enlargement with subsequent involution has been reported in patients with PROP1 mutations (61). The mechanism, however, underlying this phenomenon remains still unknown. 


\section{IGHD Type II}

Focusing on the autosomal dominant form of IGHD, type II (IGHD II) is mainly caused by mutations within the first six bp of intervening sequences 3 (5'IVS-3) (8,62-66), which result in a missplicing at the mRNA level and the subsequent loss of E3, producing a $17.5-\mathrm{kDa} \mathrm{hGH}$ isoform $(8,65)$. This GH product lacks aa 32-71 (del32-71 GH), which is the entire loop that connects helix 1 and helix 2 in the tertiary structure of hGH $(67,68)$. Skipping of E3 caused by $\mathrm{GH}-1$ gene alterations other than those at the donor splice site in 5'IVS-3 has also been reported in other patients with IGHD II. These include mutations in exon 3 (E3) splice enhancer ESE1 (E3+1G->T:ESE1m1; E3+2A->C:ESE1m2, E3+5A->G:ESE1m3) as well as ESE2 (downstream of the cryptic splice site in E3; ESE2: $\Delta 721-735)$ and within suggested intron splice enhancers (ISE) (IVS-3+28 G->A: ISEm1; IVS-3del+28-45: ISEm2) sequences (8,64,69-75). Such mutations lie within purine-rich sequences and cause increased levels of E3 skipped transcripts (64,69-71,73-75), suggesting that the usage of the normal splicing elements (ESE1 at the $5^{\prime}$ end of E3 as well as ISE in intron 3) may be disrupted (73-75). Importantly, the first 7 nucleotides in E3 (ESE1) are crucial for the splicing of GH mRNA (75) such that some nonsense mutations might cause skipping of one or even more exons during mRNA splicing in the nucleus. This phenomenon is called nonsense-mediated altered splicing (NAS); its underlying mechanisms are still unknown (76). Furthermore, there is a recent report of Vivenza et al (77)

Table 2. Transcription factors of clinical importance

\begin{tabular}{|c|c|c|}
\hline Gene & Phenotype & Inheritance \\
\hline Pit1 / POU1F1 & $\begin{array}{l}\text { hormonal deficiencies: GH, PRL, TSH } \\
\text { imaging: anterior pituitary gland: normal to hypo } \\
\text { posterior pituitary gland: normal } \\
\text { other manifestation: none }\end{array}$ & $\mathrm{R} / \mathrm{D}$ \\
\hline PROP 1 & $\begin{array}{l}\text { hormonal deficiencies: GH, PRL, TSH, LH, FSH, (ACTH) } \\
\text { imaging: anterior pituitary gland: hypo to hyper } \\
\text { posterior pituitary gland: normal } \\
\text { other manifestation: none }\end{array}$ & $\mathrm{R}$ \\
\hline HESX1 & $\begin{array}{l}\text { hormonal deficiencies: GH, PRL, TSH, LH, FSH, ACTH, IGHD, CPHD } \\
\text { imaging: anterior pituitary gland: hypo } \\
\text { posterior pituitary gland: ectopic } \\
\text { other manifestation: eyes, brain, septo-optic dysplasia }\end{array}$ & $\mathrm{R} / \mathrm{D}$ \\
\hline LHX3 & $\begin{array}{l}\text { hormonal deficiencies: GH, PRL, TSH, LH, FSH (ACTH) } \\
\text { imaging: anterior pituitary gland: hypo } \\
\text { posterior pituitary gland: normal } \\
\text { other manifestation: neck rotation } 75-85^{\circ} \text { (no: } 160-180^{\circ} \text { ), } \\
\text { sensoneural hearing loss }\end{array}$ & $\mathrm{R}$ \\
\hline LHX4 & $\begin{array}{l}\text { hormonal deficiencies: GH, TSH, LH, FSH, ACTH } \\
\text { imaging: anterior pituitary gland: hypo } \\
\text { posterior pituitary gland: normal, ectopic } \\
\text { other manifestation: sella turcica / skull defects } \\
\text { cerebellar defects }\end{array}$ & D \\
\hline SOX2 & $\begin{array}{l}\text { haploinsufficiency } \\
\text { hormonal deficiencies: GH, LH, FSH } \\
\text { imaging: anterior pituitary gland: hypo } \\
\text { posterior pituitary gland: normal / hypo } \\
\text { other manifestation: bilateral anophthalmia, spastic, altered brain } \\
\text { development oesophage atresia, sensoneural } \\
\text { hearing loss }\end{array}$ & $\begin{array}{l}\text { de novo } \\
3 q 26.3-q 27 \\
\quad ? / D\end{array}$ \\
\hline SOX3 & $\begin{array}{l}\text { hormonal deficiencies: GH } \\
\text { imaging: anterior pituitary gland: normal to hypo } \\
\text { posterior pituitary gland: normal, ectopic } \\
\text { other manifestation: mental retardation, abnormality of } \\
\text { corpus callosum, absent infundibulum }\end{array}$ & $\begin{array}{l}\text { Duplication; } \\
\text { PolyA expansion } \\
\text { Xq26-q27 } \\
\text { XL }\end{array}$ \\
\hline
\end{tabular}


presenting a patient with a specific deletion within intron 3 leading to E3 skipping, which underlines the importance of intron length on the splicing machinery, as it was previously suggested by the elegant work by Ryther et al (75). In addition to the above described splice site mutations that result in the production of del32-71 $\mathrm{GH}$, three other mutations within the $\mathrm{GH}-1$ gene (missense mutations) are reported to be responsible for IGHD II, namely, the substitution of leucine for proline, histidine for arginine and phenylalanine for valine at aa positions 89 (P89V), 183 (R183H) and 110 (V110F), respectively $(66,78,79)$.

At the functional level, the 17.5-kDa isoform exhibits a dominant-negative effect on the secretion of the $22-\mathrm{kDa}$ isoforms in both tissue cultures as well as in transgenic animals (80-82). The $17.5-\mathrm{kDa}$ isoform is initially retained in the endoplasmic reticulum, disrupts the Golgi apparatus, impairs both $\mathrm{GH}$ and other hormonal trafficking (83), and partially reduces the stability of the 22-kDa isoform (80). Furthermore, transgenic mice overexpressing the $17.5-\mathrm{kDa}$ isoform exhibit a defect in the maturation of $\mathrm{GH}$ secretory vesicles and the anterior pituitary gland is hypoplastic due to a loss of the majority of somatotropes $(73,80,81)$. Trace amounts of the $17.5-\mathrm{kDa}$ isoforms, however, are normally present in children and adults of normal growth and stature (84), and heterozygosity for A731G mutation (K41R) within the newly defined ESE2 (which is important for E3 inclusion) led to approximately $20 \%$ E3 skipping resulting in both normal as well as short stature $(73,75,85)$.

From the clinical point of view, severe short stature $(<-4.5 \mathrm{SDS})$ is not present in all affected individuals, indicating that in some forms of IGHD II, growth failure is less severe than one might expect (66). It has been hypothesized that children with splice site mutations may be younger and shorter at diagnosis than their counterparts with missense mutations (66). In addition, more recent in vitro and animal data suggest that both a quantitative and qualitative difference in phenotype may result from variable splice site mutations causing differing degrees of E3 skipping (8,85-89). In summary, these data suggest that the variable phenotype of autosomal dominant GHD may reflect a threshold and a dose dependency effect of the amount of $17.5-\mathrm{kDa}$ relative to $22-\mathrm{kDa} \mathrm{hGH}(81,82,85)$. Specifically, this has a variable impact on pituitary size, as well as on onset and severity of GHD and, unexpectedly, the most severe, rapid onset forms of GHD might be subsequently associated with the evolution of other pituitary hormone deficiencies $(90,91)$.

\section{IGHD Type III}

This reported type is X-linked, recessively inherited. In these families, the affected males were immunoglobulin-as well as GH-deficient $(92,93)$. Recent studies have shown that the long arm of X-chromosome may be involved and that the disorder may be caused by mutations and/or deletions of a portion of the X-chromosome containing two loci, one necessary for normal immunoglobulin production, and the other for $\mathrm{GH}$ expression (94). In addition, Duriez et al (95) reported an exon-skipping mutation in the btk-gene of a patient with X-linked agammaglobulinemia and IGHD.

\section{Bioinactive GH}

Short stature associated with bioinactive $\mathrm{GH}$ was first suggested and described by Kowarski and co-workers in 1978 (96). It is clinically characterized by normal or slightly increased GH secretion, pathologically low IGF-I levels, and normal catch-up growth on GH-replacement therapy. On a clinical basis, additional cases of bioinactive $\mathrm{GH}$ were described in the eighties (97-101). Chihara and co-workers (102-104) reported two missense mutations (R77C and D112G) in the GH-1 gene leading to Kowarski's syndrome in two Japanese patients. However, these mutations were both found in the heterozygous state only, and furthermore, the mutation R77C was also identified in the normal-statured father. Further, six $\mathrm{GH}$ variants were suggested to be bioinactive by Millar and co-workers (85). Again, all these mutations were found in the heterozygous state and no clear correlation between laboratory/clinical phenotype and patient genotype was shown. Later, also our group described a heterozygous R77C mutation in the $\mathrm{GH}$ molecule in a patient with growth retardation and delayed pubertal development. However, no differences between wt-GH and $\mathrm{GH}-\mathrm{R} 77 \mathrm{C}$ were found by functional characterization of the GH-R77C through GHR binding, activation of JAK2/STAT5 pathway and additional secretion studies together with cell proliferation when stably GHR transfected cells (293GHR) were used $(105,106)$. On the other hand, reduced capability of $\mathrm{GH}-\mathrm{R} 77 \mathrm{C}$ to directly induce GHR/GHBP gene transcription rate could indirectly affect the levels of GHBP in the circulation of our patient. In addition, this group of patients deserves further attention, because they could represent a distinct clinical entity underlining that an altered GH peptide may cause partial $\mathrm{GH}$ insensitivity through direct impact on GHR/GHBP gene expression leading to the delay of growth and pubertal development. Finally, GH-R77C is not invariably associated with short stature, although the serum IGF-I levels are low, the GH is elevated, and the GHBP levels are somewhat low, consistent with some degree of $\mathrm{GH}$ insensitivity, which is, presumably, compensated for by excess of $\mathrm{GH}$ production. Whether this is due to $\mathrm{GH}$ receptor transcription defects, remains unclear.

Furthermore, in one of the more convincing cases of bioinactive $\mathrm{GH}$ reported to date, a homozygous missense mutation (bp:G705C; aa:C53S) leading to disruption of the disulfide bond between Cys-53 and Cys-165 was found in a short (-3.6SDS) Serbian boy. Both GHR binding as well as JAK2/STAT5 signalling activities were markedly reduced (107). 


\section{Functional Analysis of Any Gene Variant is Important}

To make the story even more complicated, we reported a patient suffering from a specific form of IGHD II caused by a $\mathrm{GH}-1$ gene alteration on a hypomorphic partial agonistic allele, emphasizing the importance of detailed functional analysis of $\mathrm{GH}$ variants. The patient was heterozygous for the $\mathrm{GH}-\mathrm{R} 178 \mathrm{H}$ mutation (108). Clinical findings combined with the experimental data of secretion studies confirmed the diagnosis of IGHD II. However, although the $\mathrm{GH}$ concentration after stimulation was reduced, admittedly supporting the diagnosis of GHD, neither the severity of short stature (-6.0 SDS at the chronological age of 5 years) nor the low IGF-1 concentrations could be fully explained. Therefore, further functional characterization of this $\mathrm{GH}$ mutant was performed through studies of GHR binding and activation of the JAK2/STAT5 pathway. Binding activity and the bioactivity of $\mathrm{GH}-\mathrm{R} 178 \mathrm{H}$ were investigated and compared with the wt-GH and revealed that $\mathrm{GH}-\mathrm{R} 178 \mathrm{H}$ by itself behaves more like a partial agonist. Therefore, phenotype and hormonal data underlined the fact that $\mathrm{GH}-\mathrm{R} 178 \mathrm{H}$ mutation expressed from a hypomorphic partial agonistic allele seems to functionally overlie IGHD II in our patient (108).

\section{References}

1. Chen EY, Liao YC, Smith DH, Barrera-Saldana HA, Gelinas RE, Seeburg $\mathrm{PH}$. The human growth hormone locus: nucleotide sequence, biology, and evolution. Genomics 1989;4:479-497. [Abstract] / [PDF]

2. Phillips JAI. Inherited defects in growth hormone syntehsis and action. In: Scriver CR, Beaudet AL, Sly WS, Valle W (eds). The Metabolic and Molecular Basis of inherited disease. 7 ed. New York, McGraw-Hill, 1995;3023-3044.

3. Rosenfeld RG, Cohen, P. Disorders of growth hormone/ Insulin-like Growth Factor secretion and action. In: Sperling MA (ed). Pediatric Endocrinology. 2ed. Philadelphia, Saunders, 2002;211-288.

4. Baumann G. Growth hormone heterogeneity: genes, isohormones, variants, and binding proteins. Endocr Rev 1991;12:424-449. [Abstract] / [PDF]

5. DeNoto FM, Moore DD, Goodman HM. Human growth hormone DNA sequence and mRNA structure: possible alternative splicing. Nucleic Acids Res 1981;9:3719-3730. [Abstract] / [PDF]

6. Lewis UJ, Bonewald LF, Lewis LJ. The 20,000-dalton variant of human growth hormone: location of the amino acid deletions. Biochem Biophys Res Commun 1980;92:511-516. [Abstract] / [PDF]

7. Nuoffer JM, Fluck C, Deladoey J, Eble A, Dattani MT, Mullis $\mathrm{PE}$. Regulation of human $\mathrm{GH}$ receptor gene transcription by 20 and $22 \mathrm{kDa} \mathrm{GH}$ in a human hepatoma cell line. J Endocrinol 2000;165:313-320. [Abstract] / [PDF]

8. Mullis PE. Genetic control of growth. Eur J Endocrinol 2005;152:11-31. [Abstract] / [Full Text] / [PDF]

9. Lacey KA, Parkin JM. Causes of short stature. A community study of children in Newcastle upon Tyne. Lancet 1974;1:42-5. [Abstract]
10. Rona RJ, Altman DG. National study of health and growth: standards of attained height, weight and triceps skinfold in English children 5 to 11 years old. Ann Hum Biol 1977;4:501-523. [Abstract] / [Full Text]

11. Vimpani GV, Vimpani AF, Lidgard GP, Cameron EH, Farquhar JW. Prevalence of severe growth hormone deficiency. Br Med J 1977;2:427-430. [Abstract] / [Full Text] / [PDF]

12. Cacciari E, Zucchini S, Carla G, Pirazzoli P, Cicognani A, Mandini M, Busacca M, Trevisan C. Endocrine function and morphological findings in patients with disorders of the hypothalamo-pituitary area: a study with magnetic resonance. Arch Dis Child 1990;65:1199-1202. [Abstract] / [Full Text] / [PDF]

13. Illig R. Growth hormone antibodies in patients treated with different preparations of human growth hormone (HGH). J Clin Endocrinol Metab 1970;31:679-688. [Abstract] / [PDF]

14. Phillips JA, 3rd, Hjelle BL, Seeburg PH, Zachmann M. Molecular basis for familial isolated growth hormone deficiency. Proc Natl Acad Sci USA 1981;78:6372-6375. [Abstract] / [Full Text] / [PDF]

15. Laron Z, Kelijman M, Pertzelan A, Keret R, Shoffner JM, Parks JS. Human growth hormone gene deletion without antibody formation or growth arrest during treatment-a new disease entity? Isr J Med Sci 1985;21:999-1006. [Abstract]

16. Duquesnoy P, Amselem S, Gourmelen M. A frameshift mutation causing isolated growth hormone deficiency type 1A. Am J Med Genet 1990;47:A110.

17. Igarashi $Y$, Ogawa M, Kamijo T, Iwatani N, Nishi $Y$, Kohno H, Masumura T, Koga J. A new mutation causing inherited growth hormone deficiency: a compound heterozygote of a $6.7 \mathrm{~kb}$ deletion and a two base deletion in the third exon of the GH-1 gene. Hum Mol Genet 1993;2:1073-1074. [PDF]

18. Cogan JD, Phillips JA, $3^{\text {rd }}$, Sakati N, Frisch H, Schober E, Milner RD. Heterogeneous growth hormone (GH) gene mutations in familial GH deficiency. J Clin Endocrinol Metab 1993;76:1224-1228. [Abstract] / [PDF]

19. Wagner JK, Eble A, Cogan JD, Prince MA, Phillips JA, $3^{\text {rd }}$, Mullis PE. Allelic variations in the human growth hormone-1 gene promoter of growth hormone-deficient patients and normal controls. Eur J Endocrinol 1997;137:474-481. [Abstract] / [PDF]

20. Phillips JA, $3^{\text {rd }}$, Cogan JD. Genetic basis of endocrine disease. 6. Molecular basis of familial human growth hormone deficiency. J Clin Endocrinol Metab 1994;78:11-16. [Abstract] / [PDF]

21. Mullis $P$, Patel $M$, Brickell PM, Brook CG. Isolated growth hormone deficiency: analysis of the growth hormone (GH)-releasing hormone gene and the $\mathrm{GH}$ gene cluster. J Clin Endocrinol Metab 1990;70:187-191. [Abstract] / [PDF]

22. Perez Jurado LA, Phillips JA, $3^{\text {rd }}$, Francke U. Exclusion of growth hormone (GH)-releasing hormone gene mutations in familial isolated $\mathrm{GH}$ deficiency by linkage and single strand conformation analysis. J Clin Endocrinol Metab 1994;78:622628. [Abstract] / [PDF]

23. Mayo KE. Molecular cloning and expression of a pituitary-specific receptor for growth hormone-releasing hormone. Mol Endocrinol 1992;6:1734-1744. [Abstract] / [PDF]

24. Lin SC, Lin CR, Gukovsky I, Lusis AJ, Sawchenko PE, Rosenfeld MG. Molecular basis of the little mouse phenotype and implications for cell type-specific growth. Nature 1993;364:208-213. [Abstract]

25. Cao Y, Wagner JK, Hindmarsh PC, Eble A, Mullis PE. Isolated growth hormone deficiency: testing the little mouse hypothesis in man and exclusion of mutations within the extracellular domain of the growth hormone-releasing hormone receptor. Pediatr Res 1995;38:962-966. [Abstract] / [PDF] 
26. Wajnrajch MP, Gertner JM, Harbison MD, Chua SC, Jr., Leibel RL. Nonsense mutation in the human growth hormone-releasing hormone receptor causes growth failure analogous to the little (lit) mouse. Nat Genet 1996;12:88-90. [Abstract] / [PDF]

27. Baumann G, Maheshwari H. The Dwarfs of Sindh: severe growth hormone $(\mathrm{GH})$ deficiency caused by a mutation in the GH-releasing hormone receptor gene. Acta Paediatr Suppl 1997;423:33-38. [Abstract]

28. Maheshwari HG, Silverman BL, Dupuis J, Baumann G. Phenotype and genetic analysis of a syndrome caused by an inactivating mutation in the growth hormone-releasing hormone receptor: Dwarfism of Sindh. J Clin Endocrinol Metab 1998;83:4065-4074. [Abstract] / [Full Text] / [PDF]

29. Netchine I, Talon P, Dastot F, Vitaux F, Goossens $M$, Amselem S. Extensive phenotypic analysis of a family with growth hormone $(\mathrm{GH})$ deficiency caused by a mutation in the GH-releasing hormone receptor gene. J Clin Endocrinol Metab 1998;83:432-436. [Abstract] / [Full Text] / [PDF]

30. Salvatori $R$, Hayashida $\mathrm{CY}$, Aguiar-Oliveira MH, Phillips JA, $3^{\text {rd }}$ Souza AH, Gondo RG, Toledo SP, Conceicão MM, Prince M, Maheshwari HG, Baumann G, Levine MA. Familial dwarfism due to a novel mutation of the growth hormone-releasing hormone receptor gene. J Clin Endocrinol Metab 1999;84:917923. [Abstract] / [Full Text] / [PDF]

31. Salvatori R, Fan X, Phillips JA, $3^{\text {rd }}$, Espigares-Martin R, Martin De Lara I, Freeman KL, Plotnick L, Al-Ashwal A, Levine MA. Three new mutations in the gene for the growth hormone (gh)-releasing hormone receptor in familial isolated gh deficiency type ib. J Clin Endocrinol Metab 2001;86:273-279. [Abstract] / [Full Text] / [PDF]

32. Alba M, Hall CM, Whatmore AJ, Clayton PE, Price DA Salvatori R. Variability in anterior pituitary size within members of a family with $\mathrm{GH}$ deficiency due to a new splice mutation in the GHRH receptor gene. Clin Endocrinol (Oxf) 2004;60:470-475. [Abstract] / [PDF]

33. Osorio MG, Marui S, Jorge AA, Latronico AC, Lo LS, Leite CC, Estefan V, Mendonca BB, Arnhold IJ. Pituitary magnetic resonance imaging and function in patients with growth hormone deficiency with and without mutations in GHRH-R, GH-1, or PROP-1 genes. J Clin Endocrinol Metab 2002:87:5076-5084. [Abstract] / [Full Text] / [PDF]

34. Billestrup N, Swanson LW, Vale W. Growth hormone-releasing factor stimulates proliferation of somatotrophs in vitro. Proc Natl Acad Sci USA 1986;83:6854-6857. [Abstract] / [Full Text] / [PDFI

35. Hilal $L$, Hajaji $Y$, Vie-Luton MP, Ajaltouni $Z$, Benazzouz $B$, Chana M, Chra"bi A, Kadiri A, Amselem S, Sobrier ML. Unusual phenotypic features in a patient with a novel splice mutation in the GHRHR gene. Mol Med 2008;14:286-292. [Abstract] / [Full Text] / [PDF]

36. Martari M, Salvatori R. Chapter 3 Diseases Associated with Growth Hormone-Releasing Hormone Receptor (GHRHR) Mutations. Prog Mol Biol Transl Sci 2009;88:57-84. [Abstract] / [PDF]

37. Alatzoglou KS, Turton JP, Kelberman D, Clayton PE, Mehta A, Buchanan C, Aylwin S, Crowne EC, Christesen HT, Hertel NT Trainer PJ, Savage MO, Raza J, Banerjee K, Sinha SK, Ten S, Mushtaq T, Brauner R, Cheetham TD, Hindmarsh PC, Mullis $\mathrm{PE}$, Dattani MT. Expanding the spectrum of mutations in $\mathrm{GH} 1$ and GHRHR: genetic screening in a large cohort of patients with congenital isolated growth hormone deficiency. J Clin Endocrinol Metab 2009:94:3191-3199. [Abstract] / [Full Text] / [PDF]

38. Dieguez C, Page MD, Peters JR, Scanlon MF. Growth hormone and its modulation. J R Coll Physicians Lond 1988;22:84-91. [Abstract]

39. Wess J, Eglen RM, Gautam D. Muscarinic acetylcholine receptors: mutant mice provide new insights for drug development. Nat Rev Drug Discov 2007;6:721-733. [Abstract] / [Full Text] / [PDF]
40. Gautam D, Jeon J, Starost MF, Han SJ, Hamdan FF, Cui Y Parlow AF, Gavrilova O, Szalayova I, Mezey E, Wess J. Neuronal M3 muscarinic acetylcholine receptors are essential for somatotroph proliferation and normal somatic growth. Proc Natl Acad Sci USA 2009;106:6398-6403. [Abstract] / [Full Text] / [PDF]

41. Alba M, Salvatori R. A mouse with targeted ablation of the growth hormone-releasing hormone gene: a new model of isolated growth hormone deficiency. Endocrinology 2004;145:4134-4143. [Abstract] / [Full Text] / [PDF]

42. Mohamadi A, Martari M, Holladay CD, Phillips JA, $3^{\text {rd }}$, Mullis $P E$, Salvatori R. Mutation analysis of the muscarinic cholinergic receptor aenes in isolated arowth hormone deficiency type IB. J Clin Endocrinol Metab 2009;94:2565-2570. [Abstract] / [Full Text] / [PDF]

43. Pantel J, Legendre M, Cabrol S, Hilal L, Hajaji Y, Morisset S, Vie-Luton MP, Grouselle D, de Kerdanet M, Kadiri A, Epelbaum J, Le Bouc Y, Amselem S. Loss of constitutive activity of the growth hormone secretagogue receptor in familial short stature. J Clin Invest 2006;116:760-768. [Abstract] / [Full Text] / [PDF]

44. Pantel J, Legendre M, Nivot S, Morisset S, Vie-Luton MP, le Bouc Y, Epelbaum J, Amselem S. Recessive isolated growth hormone deficiency and mutations in the ghrelin receptor. J Clin Endocrinol Metab 2009;94:4334-4341. [Abstract] / [Full Text] / [PDF]

45. Kojima M, Hosoda $H$, Date $Y$, Nakazato $M$, Matsuo $H$, Kangawa K. Ghrelin is a growth-hormone-releasing acylated peptide from stomach. Nature 1999;402:656-660. [Abstract]

46. Thomas PQ, Dattani MT, Brickman JM, McNay D, Warne G, Zacharin M, Cameron F, Hurst J, Woods K, Dunger D, Stanhope R, Forrest S, Robinson IC, Beddington RS. Heterozygous HESX1 mutations associated with isolated congenital pituitary hypoplasia and septo-optic dysplasia. Hum Mol Genet 2001;10:39-45. [Abstract] / [Full Text] / [PDF]

47. Alatzoglou KS, Dattani MT. Genetic forms of hypopituitarism and their manifestation in the neonatal period. Early Hum Dev 2009:85:705-712. [Abstract] / [Full Text] / [PDF]

48. Woods KS, Cundall M, Turton J, Rizotti K, Mehta A, Palmer R, Wong J, Chong WK, Al-Zyoud M, El-Ali M, Otonkoski T, Martinez-Barbera JP, Thomas PQ, Robinson IC, Lovell-Badge R, Woodward KJ, Dattani MT. Over- and underdosage of SOX3 is associated with infundibular hypoplasia and hypopituitarism. Am J Hum Genet 2005;76:833-849. [Abstract] / [Full Text]

49. Solomon NM, Ross SA, Morgan T, Belsky JL, Hol FA, Karnes PS, Hopwood NJ, Myers SE, Tan AS, Warne GL, Forrest SM, Thomas PQ. Array comparative genomic hybridisation analysis of boys with $X$ linked hypopituitarism identifies a $3.9 \mathrm{Mb}$ duplicated critical region at Xa27 containing SOX3. J Med Genet 2004:41:669-678. [Abstract] / [Full Text] / [PDF]

50. Alatzoglou KS, Kelberman D, Dattani MT. The role of SOX proteins in normal pituitary development. J Endocrinol 2009;200:245-258. [Abstract] / [Full Text] / [PDF]

51. Mullis $\mathrm{P}$, Eblé, A, Wagner JK. Isolated growth hormone deficiency is associated with a $211 \mathrm{bp}$ deletion within RAR a gene. Hormone Research 1994;41:61

52. Tatsumi K, Miyai K, Notomi T, Kaibe K, Amino N, Mizuno Y, Kohno H. Cretinism with combined hormone deficiency caused by a mutation in the PIT1 gene. Nat Genet 1992;1:56-58. [Abstract] / [PDF]

53. Cohen LE, Wondisford FE, Radovick S. Role of Pit-1 in the gene expression of growth hormone, prolactin, and thyrotropin. Endocrinol Metab Clin North Am 1996;25:523-540. [Abstract] / [Full Text] / [PDF]

54. Kishimoto M, Okimura Y, Fumoto M, Iguchi G, lida K, Kaji H, Chihara K. The R271W mutant form of Pit-1 does not act as a dominant inhibitor of Pit-1 action to activate the promoters of GH and prolactin genes. Eur J Endocrinol 2003;148:619-625. [Abstract] / [PDF] 
55. Okamoto N, Wada Y, Ida S, Koga R, Ozono K, Chiyo H, Hayashi A, Tatsumi K. Monoallelic expression of normal mRNA in the PIT1 mutation heterozygotes with normal phenotype and biallelic expression in the abnormal phenotype. Hum Mol Genet 1994;3:1565-1568. [Abstract] / [PDF]

56. Wu W, Cogan JD, Pfaffle RW, Dasen JS, Frisch H, O'Connell SM, Flynn SE, Brown MR, Mullis PE, Parks JS, Phillips JA $3^{\text {rd }}$ Rosenfeld MG. Mutations in PROP1 cause familial combined pituitary hormone deficiency. Nat Genet 1998;18:147-149. [Abstract] / [PDF]

57. Sornson MW, Wu W, Dasen JS, Flynn SE, Norman DJ, O'Connell SM, Gukovsky I, Carrière C, Ryan AK, Miller AP, Zuo L, Gleiberman AS, Andersen B, Beamer WG, Rosenfeld MG. Pituitary lineage determination by the Prophet of Pit-1 homeodomain factor defective in Ames dwarfism. Nature 1996;384:327-333. [Abstract] / [PDF]

58. Fluck C, Deladoey J, Rutishauser K, Eble A, Marti U, Wu W, Mullis PE. Phenotypic variability in familial combined pituitary hormone deficiency caused by a PROP1 gene mutation resulting in the substitution of Arg-->Cys at codon 120 (R120C). J Clin Endocrinol Metab 1998;83:3727-3734. [Abstract] / [Full Text] / [PDF]

59. Duquesnoy P, Roy A, Dastot F, Ghali I, Teinturier C, Netchine I, Cacheux V, Hafez M, Salah N, Chaussain JL, Goossens M, Bougnères $\mathrm{P}$, Amselem S. Human Prop-1: cloning, mapping, genomic structure. Mutations in familial combined pituitary hormone deficiency. FEBS Lett 1998;437:216-220. [Abstract] / [Full Text]

60. Deladoey J, Fluck C, Buyukgebiz A, Kuhlmann BV, Eble A, Hindmarsh PC, Wu W, Mullis PE. "Hot spot" in the PROP1 gene responsible for combined pituitary hormone deficiency. J Clin Endocrinol Metab 1999;84:1645-650. [Abstract] / [Full Text] / [PDF]

61. Mendonca BB, Osorio MG, Latronico AC, Estefan V, Lo LS, Arnhold IJ. Longitudinal hormonal and pituitary imaging changes in two females with combined pituitary hormone deficiency due to deletion of A301,G302 in the PROP1 gene. J Clin Endocrinol Metab 1999;84:942-945. [Abstract] / [Full Text] / [PDF]

62. Missarelli C, Herrera L, Mericq V, Carvallo P. Two different $5^{\prime}$ splice site mutations in the growth hormone gene causing autosomal dominant growth hormone deficiency. Hum Genet 1997;101:113-117. [Abstract] / [PDF]

63. Cogan JD, Phillips JA, $3^{\text {rd }}$, Schenkman SS, Milner RD, Sakati $\mathrm{N}$. Familial growth hormone deficiency: a model of dominant and recessive mutations affecting a monomeric protein. J Clin Endocrinol Metab 1994;79:1261-1265. [Abstract] / [PDF]

64. Cogan JD, Ramel B, Lehto M, Phillips J, $3^{\text {rd }}$, Prince M, Blizzard RM, de Ravel TJ, Brammert M, Groop L. A recurring dominant negative mutation causes autosomal dominant growth hormone deficiency-a clinical research center study. J Clin Endocrinol Metab 1995;80:3591-3595. [Abstract] / [PDF]

65. Binder G, Ranke MB. Screening for growth hormone $(G H)$ gene splice-site mutations in sporadic cases with severe isolated GH deficiency using ectopic transcript analysis. J Clin Endocrinol Metab 1995;80:1247-1252. [Abstract] / [PDF]

66. Binder G, Keller E, Mix M, Massa GG, Stokvis-Brantsma WH, Wit JM, Ranke MB. Isolated GH deficiency with dominant inheritance: new mutations, new insights. J Clin Endocrinol Metab 2001;86:3877-3881. [Abstract] / [Full Text] / [PDF]

67. de Vos AM, Ultsch M, Kossiakoff AA. Human growth hormone and extracellular domain of its receptor: crystal structure of the complex. Science 1992;255:306-312. [Abstract] / [PDF]

68. Cunningham BC, Ultsch $M$, De Vos AM, Mulkerrin MG, Clauser KR, Wells JA. Dimerization of the extracellular domain of the human growth hormone receptor by a single hormone molecule. Science 1991;254:821-825. [Abstract] / [PDF]
69. Cogan JD, Prince MA, Lekhakula S, Bundey S, Futrakul A, McCarthy EM, Phillips JA 3rd. A novel mechanism of aberrant pre-mRNA splicing in humans. Hum Mol Genet 1997;6:909-912. [Abstract] / [Full Text] / [PDF]

70. Takahashi I, Takahashi T, Komatsu M, Sato T, Takada G. An exonic mutation of the $\mathrm{GH}-1$ gene causing familial isolated growth hormone deficiency type II. Clin Genet 2002;61:222-225. [Abstract] / [Full Text] / [PDF]

71. Moseley CT, Mullis PE, Prince MA, Phillips JA, $3^{\text {rd }}$. An exon splice enhancer mutation causes autosomal dominant $\mathrm{GH}$ deficiency. J Clin Endocrinol Metab 2002;87:847-852. [Abstract] / [Full Text] / [PDF]

72. Mullis PE, Deladoey J, Dannies PS. Molecular and cellular basis of isolated dominant-negative growth hormone deficiency, IGHD type II: insights on the secretory pathway of peptide hormones. Horm Res 2002;58:53-66. [Abstract] / [Full Text] / [PDF]

73. Ryther RC, McGuinness LM, Phillips JA, $3^{\text {rd }}$, Moseley CT, Magoulas CB, Robinson IC, Patton JG. Disruption of exon definition produces a dominant-negative growth hormone isoform that causes somatotroph death and IGHD II. Hum Genet 2003;113:140-148. [Abstract] / [Full Text] / [PDF]

74. McCarthy EM, Phillips JA, $3^{\text {rd }}$. Characterization of an intron splice enhancer that regulates alternative splicing of human GH pre-mRNA. Hum Mol Genet 1998;7:1491-1496. [Abstract] / [Full Text] / [PDF]

75. Ryther RC, Flynt AS, Harris BD, Phillips JA, $3^{\text {rd }}$, Patton JG. $\mathrm{GH} 1$ splicing is regulated by multiple enhancers whose mutation produces a dominant-negative $\mathrm{GH}$ isoform that can be degraded by allele-specific small interfering RNA (siRNA). Endocrinology 2004;145:2988-2996. [Abstract] / [Full Text] / [PDF]

76. Dietz HC. Nonsense mutations and altered splice-site selection. Am J Hum Genet 1997;60:729-730.[Full Text] / [PDF]

77. Vivenza D, Guazzarotti L, Godi M, Frasca D, di Natale B, Momigliano-Richiardi $P$, Bona G, Giordano M. A novel deletion in the $\mathrm{GH} 1$ gene including the IVS3 branch site responsible for autosomal dominant isolated growth hormone deficiency. J Clin Endocrinol Metab. 2006;91:980-6. [Abstract] / [Full Text] / [PDF]

78. Deladoey J, Stocker P, Mullis PE. Autosomal dominant GH deficiency due to an $\mathrm{Arg} 183 \mathrm{His} \mathrm{GH}-1$ gene mutation: clinical and molecular evidence of impaired regulated $\mathrm{GH}$ secretion. J Clin Endocrinol Metab 2001;86:3941-3947. [Abstract] / [Full Text] / [PDF]

79. Familial isolated growth hormone deficiency with slight height reduction due to a heterozygote mutation in $\mathrm{GH}$ gene. Duquesnoy P, Simon, D, Netchine I. New Orleans, Program of the $80^{\text {th }}$ Annual meeting of The Endocrine Society, 1998;202.

80. Lee MS, Wajnrajch MP, Kim SS, Plotnick LP, Wang J, Gertner JM, Leibel RL, Dannies PS. Autosomal dominant growth hormone $(\mathrm{GH})$ deficiency type II: the Del32-71-GH deletion mutant suppresses secretion of wild-type GH. Endocrinology 2000;141:883-890. [Abstract] / [Full Text] / [PDF]

81. McGuinness L, Magoulas C, Sesay AK, Mathers K, Carmignac D, Manneville JB, Christian H, Phillips JA $3^{\text {rd }}$, Robinson IC. Autosomal dominant growth hormone deficiency disrupts secretory vesicles in vitro and in vivo in transgenic mice. Endocrinology 2003;144:720-731. [Abstract] / [Full Text] / [PDF]

82. Hayashi Y, Yamamoto M, Ohmori S, Kamijo T, Ogawa M, Seo $\mathrm{H}$. Inhibition of growth hormone $(\mathrm{GH})$ secretion by a mutant $\mathrm{GH}-\mathrm{I}$ gene product in neuroendocrine cells containing secretory granules: an implication for isolated GH deficiency inherited in an autosomal dominant manner. J Clin Endocrinol Metab 1999;84:2134-2139. [Abstract] / [Full Text] / [PDF] 
83. Graves TK, Patel S, Dannies PS, Hinkle PM. Misfolded growth hormone causes fragmentation of the Golgi apparatus and disrupts endoplasmic reticulum-to-Golgi traffic. J Cell Sci 2001;114:3685-3694. [Abstract] / [Full Text] / [PDF]

84. Lewis UJ, Sinha YN, Haro LS. Variant forms and fragments of human growth hormone in serum. Acta Paediatr Suppl. 1994;399:29-31; discussion 2. [Abstract]

85. Millar DS, Lewis MD, Horan M, Newsway V, Easter TE, Gregory JW, Fryklund L, Norin M, Crowne EC, Davies SJ, Edwards P, Kirk J, Waldron K, Smith PJ, Phillips JA $3^{\text {rd }}$, Scanlon MF, Krawczak M, Cooper DN, Procter AM. Novel mutations of the growth hormone $1(\mathrm{GH} 1)$ gene disclosed by modulation of the clinical selection criteria for individuals with short stature. Hum Mutat 2003;21:424-440. [Abstract] / [PDF]

86. Fofanova OV, Evgrafov OV, Polyakov AV, Poltaraus $A B$, Peterkova VA, Dedov II. A novel IVS2 -2A>T splicing mutation in the $\mathrm{GH}-1$ gene in familial isolated growth hormone deficiency type $\mathrm{II}$ in the spectrum of other splicing mutations in the Russian population. J Clin Endocrinol Metab 2003:88:820-826. [Abstract] / [Full Text] / [PDF]

87. Katsumata N, Matsuo S, Sato N, Tanaka T. A novel and de novo splice-donor site mutation in intron 3 of the $\mathrm{GH}-1$ gene in a patient with isolated growth hormone deficiency. Growth Horm IGF Res 2001;11:378-383. [Abstract] / [PDF]

88. Kamijo T, Hayashi Y, Seo H, Ogawa M. Hereditary isolated growth hormone deficiency caused by $\mathrm{GH} 1$ gene mutations in Japanese patients. Growth Horm IGF Res 1999;9:31-6. [Abstract] / [PDF]

89. Kamijo T, Hayashi Y, Shimatsu A, Kinoshita E, Yoshimoto M, Ogawa M, Seo H. Mutations in intron 3 of $\mathrm{GH}-1$ gene associated with isolated GH deficiency type II in three Japanese families. Clin Endocrinol (Oxf) 1999;51:355-360. [Abstract] / [Full Text] / [PDF]

90. Mullis PE, Robinson IC, Salemi S, Eble A, Besson A, Vuissoz JM, Deladoey J, Simon D, Czernichow P, Binder G. Isolated autosomal dominant growth hormone deficiency: an evolving pituitary deficit? A multicenter follow-up study. J Clin Endocrinol Metab 2005;90:2089-2096. [Abstract] / [Full Text] / [PDF]

91. Salemi S, Yousefi S, Baltensperger K, Robinson IC, Eble A, Simon D, Czernichow P, Binder G, Sonnet E, Mullis PE. Variability of isolated autosomal dominant $\mathrm{GH}$ deficiency (IGHD II): impact of the P89L GH mutation on clinical follow-up and GH secretion. Eur J Endocrinol 2005;153:791-802. [Abstract] / [Full Text] / [PDF]

92. Fleisher TA, White RM, Broder S, Nissley SP, Blaese RM, Mulvihill JJ, Olive G, Waldmann TA. X-linked hypogammaglobulinemia and isolated growth hormone deficiency. N Engl J Med 1980;302:1429-1434. [Abstract]

93. Sitz KV, Burks AW, Williams LW, Kemp SF, Steele RW. Confirmation of X-linked hypogammaglobulinemia with isolated growth hormone deficiency as a disease entity. J Pediatr 1990;116:292-294. [Abstract] / [PDF]

94. Conley ME, Burks AW, Herrod HG, Puck JM. Molecular analysis of $X$-linked agammaglobulinemia with growth hormone deficiency. J Pediatr 1991;119:392-397. [Abstract] / [PDF]
95. Duriez B, Duquesnoy P, Dastot F, Bougneres P, Amselem S, Goossens M. An exon-skipping mutation in the btk gene of a patient with X-linked agammaglobulinemia and isolated growth hormone deficiency. FEBS Lett 1994;346:165-170. [Abstract]

96. Kowarski AA, Schneider J, Ben-Galim E, Weldon VV, Daughaday WH. Growth failure with normal serum RIA-GH and low somatomedin activity: somatomedin restoration and growth acceleration after exogenous GH. J Clin Endocrinol Metab 1978;47:461-464. [Abstract] / [PDF]

97. Rudman D, Kutner MH, Blackston RD, Cushman RA, Bain RP, Patterson JH. Children with normal-variant short stature: treatment with human growth hormone for six months. N Engl J Med 1981;305:123-131. [Abstract]

98. Frazer T, Gavin JR, Daughaday WH, Hillman RE, Weldon VV. Growth hormone-dependent growth failure. J Pediatr 1982;101:12-15. [Abstract] / [PDF]

99. Plotnick LP, Van Meter QL, Kowarski AA. Human growth hormone treatment of children with growth failure and normal growth hormone levels by immunoassay: lack of correlation with somatomedin generation. Pediatrics 1983;71:324-327. [Abstract] / [Full Text]

100. Hayek A, Peake GH. A new syndrome of short stature due to to biologically inactive but immunoreactive growth hormone. Pediatr Res 1978;12:413. [PDF]

101. Bright CM, Rogol AD, Johanson AJ, Blizzard RM. Short stature associated with normal growth hormone and decreased somatomedin-C concentrations: response to exogenous growth hormone. Pediatrics 1983;71:576-580. [Abstractl / [PDF]

102. Chihara K, Takahashi Y, Kaji H, Goji K, Okimura Y, Abe H. Short stature caused by a natural growth hormone antagonist. Horm Res 1998;49:41-45. [Abstract] / [Full Text] / [PDF]

103. Takahashi Y, Shirono H, Arisaka O, Takahashi K, Yagi T, Koga $\mathrm{J}$, Kaji H, Okimura Y, Abe H, Tanaka T, Chihara K. Biologically inactive growth hormone caused by an amino acid substitution. J Clin Invest 1997;100:1159-1165. [Abstract] / [PDF]

104. Takahashi Y, Kaji H, Okimura Y, Goji K, Abe H, Chihara K. Brief report: short stature caused by a mutant growth hormone. N Engl J Med 1996;334:432-436. [Abstract] / [Full Text]

105. Petkovic V, Besson A, Thevis M, Lochmatter D, Eble A, Fluck $\mathrm{CE}$, Mullis PE. Evaluation of the biological activity of a growth hormone $(\mathrm{GH})$ mutant (R77C) and its impact on $\mathrm{GH}$ responsiveness and stature. J Clin Endocrinol Metab 2007;92:2893-2901. [Abstract] / [Full Text] / [PDF]

106. Petkovic V, Thevis M, Lochmatter D, Besson A, Eble A, Fluck $\mathrm{CE}$, Mullis PE. GH mutant $(\mathrm{R} 77 \mathrm{C})$ in a pedigree presenting with the delay of growth and pubertal development: structural analysis of the mutant and evaluation of the biological activity. Eur J Endocrinol 2007;157:67-74. [Abstract] / [Full Text] / [PDF]

107. Besson A, Salemi S, Deladoey J, Vuissoz JM, Eble A, Bidlingmaier $M$, Bürgi $S$, Honegger $U$, Flück $C$, Mullis PE. Short stature caused by a biologically inactive mutant growth hormone (GH-C53S). J Clin Endocrinol Metab 2005;90:2493-2499. [Abstract] / [Full Text] / [PDF]

108. Petkovic V, Godi M, Pandey AV, Lochmatter D, Buchanan CR, Dattani MT, Eblé A, Flück CE, Mullis PE. Growth hormone (GH) deficiency type II: a novel GH-1 gene mutation (GH-R178H) affecting secretion and action. J Clin Endocrinol Metab 2010;95:731-739. [Abstract] / [Full Text] / [PDF] 